\title{
Lethal and sublethal effects of spirotetramat and abamectin on predatory beetles (Menochilus sexmaculatus) via prey (Agonoscena pistaciae) exposure, important for integrated pest management in pistachio orchards
}

\author{
Fahimeh Azod ${ }^{1}$, Shahnaz Shahidi-Noghabi ${ }^{1, *}$, Kamran Mahdian ${ }^{1}$ \& Guy Smagghe ${ }^{2}$
}

1 Department of Plant Protection, Faculty of Agriculture, Vali-e-Asr University of Rafsanjan, Rafsanjan, Iran

2 Department of Crop Protection, Ghent University, Ghent, Belgium

* Corresponding author: shahidi@vru.ac.ir

\begin{abstract}
Menochilus sexmaculatus Fabricius (Coleoptera: Coccinellidae) is an important biological control agent in pistachio orchards, especially against Agonoscena pistaciae Burckhardt and Lauterer (Hemiptera: Psyllidae), which is the most damaging pest of pistachio. In this project we exposed M. sexmaculatus adults to two important commonly-used insecticides through feeding on treated prey (A. pistaciae) to evaluate the side-effects on this predator. We tested spirotetramat, which belongs to the keto-enol group inhibiting lipid biosynthesis in insects, at $2 / 1,1 / 1$ and $1 / 2$ of the maximum field recommended concentration (MFRC), and abamectin, which is a mixture of avermectins and a natural fermentation product of the bacterium Streptomyces avermitilis, at 1/1, $1 / 2,1 / 4,1 / 8$ and 1/16 of its MFRC. Spirotetramat did not affect adult survival of $M$. sexmaculatus at all three concentrations when ingested via treated prey, while in marked contrast abamectin caused $100 \%$ adult mortality of M. sexmaculatus when ingested via treated prey at 1/1,1/2,1/4 and 1/8 of the MFRC. At sublethal levels, spirotetramat reduced total and daily fecundity of $M$. sexmaculatus at all three concentrations tested, but did not affect egg hatching at 1/1 and 1/2 of the MFRC. Moreover, prey consumption was decreased when beetles were exposed to the prey treated with spirotetramat at $1 / 1$ and 2/1 of the MFRC concentrations. With abamectin, even at 1/16 of the MFRC, total fecundity, daily fecundity and prey consumption of $M$. sexmaculatus adults were significantly affected. In conclusion, no acute toxicity was observed on $M$. sexmaculatus by ingestion of prey treated with spirotetramat, although reproduction parameters and prey consumption were affected at MFRC and lower concentrations. In marked contrast, abamectin was notably very harmful at its MFRC and also at lower concentrations. This research highlighted the importance of toxicity risk assessments, including lethal and sublethal effects, to obtain a more accurate estimation of the compatibility of insecticides in current integrated pest management (IPM) programs.
\end{abstract}

KEY WORDS: abamectin, Agonoscena pistaciae, Menochilus sexmaculatus, predators, spirotetramat, sublethal effects

\section{INTRODUCTION}

The common pistachio psyllid, Agonoscena pistaciae Burckhardt and Lauterer (Hemiptera: Psyllidae), is the most damaging pest of pistachio (Pistacia vera) in Iran (MEHRNEJAD, 2001). Chemical control is a common method in management of this pest. However, continued use of chemical insecticides has made A. pistaciae resistant to the insecticides that are currently used. Additionally, some of these pesticides adversely affect the biological control agents that are currently used to control the psyllid and this in turn results in new pest outbreaks (MEHRNEJAD, 2003). Coccinellids usually play a key role in integrated pest management (IPM) programs in several agroecosystems (JACAS \& URBANEJA, 2010). The ladybeetle Menochilus sexmaculatus Fabricius (Coleoptera: Coccinellidae) is an 
important biological control agent in various parts of the world, especially in East Asia. Its activities as a predator of different species of aphids and psyllids have been reported, but because of the physiological similarity between the pest and the natural enemy, pesticides often cause mortality in both groups of organisms (CROFT, 1990). In addition to the direct lethal effects of pesticides, estimated on the basis of mortality rate, sublethal effects of pesticides can also strongly influence physiology and behavior, affecting the population build-up and predation capacities of natural enemies (JOHNSON \& TABASHNIK, 1999). Spirotetramat is a new systemic and persistent foliar insecticide and a tetramic acid derivative with a novel mode of action, interfering with lipid biosynthesis. In 2011, the use of this pesticide was authorized in several European countries (i.e., United Kingdom, Belgium and Switzerland) in different crops, such as brassicas and lettuce to control sucking pests (BAYER CROP SCIENCE, 2012). Despite its use in several areas on different crops, information on side-effects of spirotetramat on coccinellids is still scarce (BRUCK et al., 2009). The few studies available have categorized this lipid biosynthesis inhibitor as harmless to other natural enemies, such as the predators Episyrphus balteatus (de Geer) (Diptera: Syrphidae) and Chrysoperla carnea (Stephens) (Neuroptera: Chrysopidae) (SCHNORBACH et al., 2008; MoENs et al., 2011), Cryptolaemus montrouzieri Mulsant (Coleoptera: Coccinellidae) (PlaneS et al., 2013). Abamectin is a naturally derived acaricide/insecticide isolated from fermentation of the soil microorganism Streptomyces avermitilis. Susceptibility to abamectin has been shown for several ladybeetle species (Coleoptera: Coccinellidae), including Harmonia axyridis Pallas, Cryptolaemus sp., Cycloneda sanguinea Linnaeus, and Stethorus punctum (LeConte) larvae and adults (MICHAUD, 2002; YOUAN, 2003; SEAL et al., 2006).

The assessment of pesticides in the registration procedure and for compatibility in IPM programs usually begins with a calculation of their acute toxicity, which provides essential information on the risk they may pose against natural enemies (CANDOLFI et al., 2001). However, researchers have documented the importance of sublethal effects of insecticides on different biological parameters of predators and parasitoids (BIONDI et al., 2012). Recently, studies have been done on biological and behavioral influences of insecticides on natural enemies (SCHNEIDER et al., 2008; DELPUECH et al., 2012; WRINN et al., 2012; ZOTTI et al., 2013). Therefore, the objective of this study was to assess the lethal and sublethal side-effects of spirotetramat and abamectin, two insecticides that are commonly used in pistachio orchards of Iran, on the adults of $M$. sexmaculatus. We exposed the predator to the insecticides at several concentrations relative to their maximum concentrations as recommended for use in the field (MFRC), via feeding on treated prey. These data are important for an adequate environmental risk assessment based on lethal and sublethal effects. The results will provide a measure of the compatibility of spirotetramat and abamectin in the current IPM programs with $M$. sexmaculatus, which is a good natural enemy against $A$. pistaciae, the key pest of pistachio in Iran.

\section{MATERIALS AND METHODS}

\section{Insect}

All developmental stages of $M$. sexmaculatus were reared in air-ventilated plastic boxes $(20 \times 25 \times 10 \mathrm{~cm})$ at $25 \pm 2^{\circ} \mathrm{C}, 65 \pm 5 \% \mathrm{RH}$ and a photoperiod of 16:8 (L:D) as previously described (FARHADI et al., 2011). In essence, the ladybeetles were provided with fresh pistachio leaves containing A. pistaciae as food. To prevent fungal growth, leaves were changed daily and the leaves containing beetle eggs were separated and transferred to Petri dishes. Due to cannibalistic behavior of the predatory larvae after hatching, individual larvae were transferred to separate Petri dishes. After two generations of breeding and feeding on $A$. pistaciae for adaptation, adults of $M$. sexmaculatus were used for experiments. 


\section{Insecticides}

Commercial formulations of spirotetramat (Movento, 10\% SC, $100 \mathrm{~g}$ of a.i./liter, Bayer Crop Science) and abamectin (Vertimec 1.8\% EC, $18 \mathrm{~g}$ of a.i. per liter, Agriphar, Belgium) were used. Spirotetramat was investigated at a dilution series of $2 / 1,1 / 1$ and $1 / 2$ of its MFRC, corresponding to 100,50 and $25 \mathrm{mg} / \mathrm{L}$, and abamectin at a dilution series of 1/1, 1/2, 1/4, 1/8 and $1 / 16$ of its MFRC, corresponding to $9,4.5$, $2.25,1.12$ and $0.56 \mathrm{mg} / \mathrm{L}$, respectively.

\section{Lethal effects of spirotetramat and abamectin on survival of adults of M. sexmaculatus}

To assess the lethal effect of spirotetramat and abamectin on $M$. sexmaculatus adults, pairs of one female and one male adult were randomly selected after we observed the first mating, and these pairs were placed in individual Petri dishes of $90 \mathrm{~mm}$ diameter. Subsequently, adult beetles were offered prey that had been treated by a dipping method (FARHADI et al., 2011) with one or the other insecticide (for spirotetramat at 2/1, 1/1 and $1 / 2$ of its MFRC, and for abamectin at $1 / 1,1 / 2,1 / 4,1 / 8$ and $1 / 16$ of its MFRC). In brief, the pistachio leaves containing $A$. pistaciae psyllids were dipped for $5 \mathrm{~s}$ in one of the different concentrations of pesticide. Then, after 0.5 hour of drying at room temperature, 150 live psyllid nymphs of the $4^{\text {th }}$ - or $5^{\text {th }}$-instar were collected from the leaves and placed on non-infected leaf discs together with one pair of $M$. sexmaculatus predatory adults. We checked mortality after 24, 48 and $72 \mathrm{~h}$. In the control groups, the leaves were dipped in distilled water. Each chemical treatment level involved three replicates of 10 pairs of adult ladybeetles.

\section{Sublethal effects of spirotetramat and abamectin on consumption of $\boldsymbol{A}$. pistaciae by M. sexmaculatus}

In this experiment, pairs of one female and one male adult were randomly selected as the first mating was observed, and each pair was placed in a separate Petri dish of $90 \mathrm{~mm}$ diameter. Subsequently, the adult beetles were fed with insecticide-treated prey using the same leaf disc dipping method as described above. Also, as above, 150 living psyllid nymphs of the $4^{\text {th }}$ - or $5^{\text {th }}$-instar were collected from the leaves and placed on non-infected leaf discs together with one pair of $M$. sexmaculatus adults. Each insecticide treatment level involved three replicates, each consisting of 10 pairs of adult beetles. In a separate experiment 10 males were each offered 70 treated psyllid nymphs of the $4^{\text {th }}$ - or $5^{\text {th }}$-instar, and studied under identical conditions to determine the number of prey that were consumed by $M$. sexmaculatus males. To calculate the daily numbers of prey eaten by females, the average number of prey eaten by males was subtracted from the average number of prey eaten by pairs (FARHADI et al., 2011). To obtain the daily feeding rate, any uneaten nymphs were collected each day and replaced by freshly treated nymphs. The prey consumption by predators was recorded daily during a period of two weeks. In the control groups, the leaves were dipped in distilled water.

\section{Sublethal effects of spirotetramat and abamectin on reproduction of M. sexmaculatus}

M. sexmaculatus adults were exposed to the two insecticides via ingestion of treated prey as described previously (FARHADI et al., 2011). In brief, for each treatment, ten pairs (male and female) were selected after first mating and each pair was placed in a separate Petri dish to determine reproductive parameters. Adults were fed daily with freshly treated prey for two weeks. Egg hatching, total fecundity, daily fecundity, pre-oviposition period and survival were recorded on a daily basis during a period of 30 days. In the control groups, the leaves were dipped in distilled water. 
TABLE 1

Lethal effect (\% mortality) of spirotetramat and abamectin at different dilutions of their respective MFRC on the survival of adults of $M$. sexmaculatus when fed on treated prey (A. pistaciae) for 24, 48 and $72 \mathrm{~h}$.

\begin{tabular}{|c|c|c|c|}
\hline & \multicolumn{3}{|c|}{ Mortality (\%) } \\
\hline & $24 \mathrm{~h}$ & $48 \mathrm{~h}$ & $72 \mathrm{~h}$ \\
\hline \multicolumn{4}{|l|}{ Spirotetramat ${ }^{1}$} \\
\hline 2/1 MFRC & $0 \pm 0^{\mathrm{a}}$ & $0 \pm 0^{\mathrm{a}}$ & $0 \pm 0^{\mathrm{a}}$ \\
\hline 1/1 MFRC & $0 \pm 0^{\mathrm{a}}$ & $0 \pm 0^{\mathrm{a}}$ & $0 \pm 0^{\mathrm{a}}$ \\
\hline $1 / 2 \mathrm{MFRC}$ & $0 \pm 0^{\mathrm{a}}$ & $0 \pm 0^{\mathrm{a}}$ & $0 \pm 0^{\mathrm{a}}$ \\
\hline \multicolumn{4}{|l|}{ Abamectin $^{2}$} \\
\hline 1/1 MFRC & $100 \pm 0^{\mathrm{c}}$ & & \\
\hline $1 / 2 \mathrm{MFRC}$ & $100 \pm 0^{c}$ & & \\
\hline 1/4 MFRC & $95 \pm 5^{c}$ & $100 \pm 0^{c}$ & \\
\hline $1 / 8 \mathrm{MFRC}$ & $0 \pm 0^{\mathrm{a}}$ & $65 \pm 5^{\mathrm{b}}$ & $100 \pm 0^{c}$ \\
\hline 1/16 MFRC & $0 \pm 0^{\mathrm{a}}$ & $0 \pm 0^{\mathrm{a}}$ & $0 \pm 0^{\mathrm{a}}$ \\
\hline
\end{tabular}

Data are expressed as mean percent mortality \pm SE. Mortality was $0 \pm 0 \%$ in the control groups. Percentages followed by different letters are significantly different $(\mathrm{P}<0.05$, Tukey HSD test).

${ }^{1}$ MFRC for spirotetramat $=50 \mathrm{mg} / \mathrm{ml}$

${ }^{2}$ MFRC for abamectin $=9 \mathrm{mg} / \mathrm{ml}$

\section{Data analysis}

Data were analyzed using SPSS software and Excel 2010. In addition, the lethal effects of the tested insecticides were categorized into four groups based on the guidelines of the International Organisation for Biological and Integrated Control (IOBC) where the toxicity is related to the life parameter reduction, expressed as percentage: harmless $(<30 \%)$, slightly harmful (30-79\%) and moderately harmful (80$99 \%$ ) to harmful $>99 \%$ (STERK et al., 1999). Biological parameters including egg-hatching, total fecundity, daily oviposition, pre-oviposition period and survival were tested for normality, and means with significant differences were separated by analysis of variance (ANOVA) followed by a Tukey HSD test at $\mathrm{P}<0.05$. Mortality score was corrected using Abbott's formula (АВВОТт, 1925).

\section{RESULTS}

\section{Lethal effects of spirotetramat and abamectin on survival of adults of M. sexmaculatus}

As shown in Tables 1 and 2, spirotetramat at the different concentrations tested $(2 / 1,1 / 1$ and
$1 / 2$ of its MFRC) posed no negative effects on the survival of adults fed treated prey during the whole experiment of $72 \mathrm{~h}$ (harmless).

In marked contrast, abamectin at $1 / 1$ and $1 / 2$ of its MFRC killed all adults within the first $24 \mathrm{~h}$ of exposure to treated prey (harmful), and even at the $1 / 4$ and $1 / 8$ of the MFRC concentration there was $100 \%$ mortality at $48 \mathrm{~h}$ and $72 \mathrm{~h}$ (harmful), respectively. With the lowest concentration tested, 1/16 of its MFRC, there was no mortality at $72 \mathrm{~h}$ (harmless).

\section{Sublethal effects of spirotetramat and abamectin on consumption of $\boldsymbol{A}$. pistaciae by \\ M. sexmaculatus}

The female adults of $M$. sexmaculatus that fed on prey treated with spirotetramat showed sublethal effects, consuming significantly fewer psyllids per day at $2 / 1$ (30\% fewer) and $1 / 1(21 \%$ fewer) of the MFRC $(\mathrm{P}<0.001)$ (Table 3$)$. At $1 / 2$ of its MFRC, spirotetramat caused only a $6 \%$ reduction in psyllid consumption, which was non-significant.

For abamectin, we tested for potential sublethal effects using of $1 / 16$ of its MFRC, because all the higher concentrations killed all adults 


\section{TABLE 2}

Toxicity categories, using IOBC guidelines, of spirotetramat and abamectin at different dilutions of their respective MFRC, based on survival of M. sexmaculatus adults when fed on treated prey (A. pistaciae) for 24, 48 and $72 \mathrm{~h}$.

\begin{tabular}{cccc} 
& & Toxicity levels & \\
\cline { 2 - 4 } & $24 \mathrm{~h}$ & $48 \mathrm{~h}$ & $72 \mathrm{~h}$ \\
\hline Spirotetramat & & & \\
$2 / 1$ MFRC & harmless & harmless & harmless \\
$1 / 1$ MFRC & harmless & harmless & harmless \\
$1 / 2$ MFRC & harmless & harmless & \\
\hline Abamectin & & & \\
$1 / 1$ MFRC & harmful & & \\
$1 / 2$ MFRC & harmful & harmful \\
$1 / 4$ MFRC & moderately harmful & slightly harmful & harmful \\
$1 / 8$ MFRC & harmless & harmless & harmless \\
$1 / 16$ MFRC & harmless & & \\
\hline
\end{tabular}

${ }^{1}$ MFRC for spirotetramat $=50 \mathrm{mg} / \mathrm{ml}$

${ }^{2} \mathrm{MFRC}$ for abamectin $=9 \mathrm{mg} / \mathrm{ml}$

within $72 \mathrm{~h}$ (Table 1). Feeding was also reduced by about $32 \%$ with exposure to this very low concentration of abamectin as compared to the control $(\mathrm{P}<0.05)$ (Table 3$)$.

\section{Sublethal effects of spirotetramat and abamectin on reproduction of M. sexmaculatus}

As shown in Table 4, adult survival was $100 \%$ during the experiment of 30 days with spirotetramat at the three concentrations tested. However, reproduction parameters were affected. The strongest effect was seen in daily fecundity and total reproduction (i.e., total number of eggs during the period of 30 days of the experiment) (both $\mathrm{P}<0.001$ ). Particularly with the highest concentration tested ( $2 / 1$ of the MFRC), daily fecundity was reduced by $64 \%$ compared to the control, and subsequently this resulted in a reduction of the total fecundity (by 66\%). In addition, these reproductive effects from $2 / 1$ of the MFRC of spirotetramat were combined with an increase of $55 \%$ in the pre-oviposition period (i.e., time needed for first oviposition) $(\mathrm{P}<0.001)$ (Table 4). In addition, for the eggs deposited by the adults that fed on prey treated with $2 / 1$ of the MFRC of spirotetramat, hatching of $1^{\text {st }}$-instar nymphs was reduced slightly $(10 \%)$ but the effect was significant $(\mathrm{P}=0.015)$.

For abamectin at 1/16 of its MFRC, the effects on reproduction were also significant (Table 4). There was a loss of adult survival of $20 \%$, total fecundity was reduced by $35 \%$ and daily fecundity by $20 \%$ (both $\mathrm{P}<0.001$ ), while preoviposition period and egg-hatching were not affected (both $\mathrm{P}>0.05$ ).

\section{DISCUSSION}

Spirotetramat is a relatively new compound mostly targeting hemipterans. It is a keto-enol derivative of tetronic acid, acting mainly by inhibiting lipogenesis following ingestion. The U.S. Environmental Protection Agency (US EPA, 2008) noted that the basic risk to bees seems to be low based on acute oral and contact experiments with honey bees. However, they reported that brood feeding trials with bees, and acute toxicity and contact studies with other non-target insects (e.g. parasitoid wasps and predatory mites) conducted at less than the maximum application rate, suggested a risk for mortality in adults and pupae, substantial agitation of brood development, and early brood 
TABLE 3

Sublethal effect of spirotetramat and abamectin at different dilutions of their respective MFRC on daily feeding rate of M. sexmaculatus females fed on treated prey (A. pistaciae) for 2 weeks, compared to the control (water).

\begin{tabular}{cccccc} 
& \multicolumn{3}{c}{ Spirotetramat $^{1}$} & Abamectin $^{2}$ & Control \\
\cline { 2 - 3 } & $2 / 1 \mathrm{MFRC}$ & $1 / 1 \mathrm{MFRC}$ & $1 / 2 \mathrm{MFRC}$ & \multirow{2}{*}{$1 / 16 \mathrm{MFRC}$} & \\
\cline { 1 - 4 } $\begin{array}{c}\text { Number of prey } \\
\text { ingested }\end{array}$ & $64.9 \pm 2.5^{\mathrm{bc}}$ & $71.6 \pm 1.3^{\mathrm{b}}$ & $85.6 \pm 1.3^{\mathrm{a}}$ & $62.2 \pm 2.4^{\mathrm{c}}$ & $90.8 \pm 0.8^{\mathrm{a}}$ \\
\hline
\end{tabular}

Data are expressed as means \pm SE. Means followed by different letters are significantly different $(\mathrm{P}<0.05$, Tukey HSD test).

${ }^{1}$ MFRC for spirotetramat $=50 \mathrm{mg} / \mathrm{ml}$

${ }^{2}$ MFRC for abamectin $=9 \mathrm{mg} / \mathrm{ml}$

termination. Currently, spirotetramat can be classified as practically non-toxic to birds and mammals on an acute basis, and practically non-toxic to honeybees based on acute oral and contact studies. Our results demonstrated no acute mortality to ladybeetles upon exposure to $2 / 1,1 / 1$ and $1 / 2$ of the MFRC. However, we found that spirotetramat reduced consumption of prey at $1 / 1$ and $1 / 2$ of the MFRC. (Spirotetramat is not a fast acting insecticide, and all prey remained alive and available for the ladybeetles to catch.) Similar results have been observed in other studies where spirotetramat reduced consumption of prey by Galendromus occidentalis (Acari: Phytoseiidae) (BEERS \& SCHMIDT, 2014). Our studies, at higher dosages of 2/1 MFRC, found that spirotetramat had a low but significant effect on egg hatching ( $10 \%$ reduction) but substantial effects on fecundity and time to first oviposition. Significant effects were even seen on fecundity from spirotetramat application at $1 / 2$ of the MFRC. These greater effects on the adult than on its eggs suggest that timing of application of this insecticide may be important in minimizing harm to this predator. Consequently, we believe that similar studies should be undertaken using more field-related conditions before spirotetramat can be recommended for use in IPM programs. Recently, BEERS \& SCHMIDT (2014) reported that spirotetramat decreased egg hatching and fecundity of $G$. occidentalis at $1 / 10,1 / 1$ and $2 / 1$ of its MFRC, but PLANES et al., 2013 did not find such effects on C. montrouzieri by similar topical treatment and ingestion. It appears that the side-effects of this insecticide may depend on the insect species. Similar to our results, several recent studies have categorized this lipid biosynthesis inhibitor as harmless to other natural enemies, such as the predators Episyrphus balteatus (Degeer) (Diptera: Syrphidae), Chrysoperla carnea (Stephens) (Neuroptera: Chrysopidae) (SCHNORBACH et al., 2008; MoENS et al., 2011), C. montrouzieri (Planes et al., 2013) and the parasitoids Microplitis mediator (Haliday) (Hymenoptera: Braconidae), Coccidoxenoides perminutus Girault (Hymenoptera: Encyrtidae) and Anagyrus sp. Near pseudococci (Hymenoptera: Encyrtidae) (MoENS et al., 2012). In another study, spirotetramat was classified as moderately toxic and, comparable to our results, it decreased fecundity in $G$. occidentalis (LEFEBVRE et al., 2011). Also PRATT \& CROFT (2000) reported that spirotetramat led to $100 \%$ adult mortality in Neoseiulus fallacis (Acari: Phytoseiidae) adversely affecting all growth stages including fecundity. However, these authors claimed that spirotetramat can be included in an IPM program if applied early in the season because most $N$. fallacis overwinter in the ground cover and later climb into the canopy; only a small proportion overwinters on the trees. Toxic effects on Typhlodromus pyri Scheuten (Acari: Phytoseiidae) in the laboratory have been reported by MAUS (2008) who also noted that in vineyards spirotetramat appeared to be non- 


\section{TABLE 4}

Adult survival and sublethal effects of spirotetramat and abamectin at different dilutions of their respective MFRC on reproduction parameters of $M$. sexmaculatus fed on treated prey (A. pistaciae) for 30 days, compared to the control (water).

\begin{tabular}{cccccc} 
& \multicolumn{3}{c}{ Spirotetramat $^{1}$} & & Abamectin \\
& & & Control \\
\cline { 2 - 4 } & $2 / 1 \mathrm{MFRC}^{1}$ & $1 / 1 \mathrm{MFRC}$ & $1 / 2 \mathrm{MFRC}$ & \\
\hline Adult survival (\%) & $100 \pm 0$ & $100 \pm 0$ & $100 \pm 0$ & $80 \pm 10$ & $100 \pm 0$ \\
\hline Egg hatching (\%) & $85.4 \pm 2.6^{\mathrm{b}}$ & $91 \pm 1.4^{\mathrm{ab}}$ & $91.2 \pm 1.5^{\mathrm{ab}}$ & $90.8 \pm 2.3^{\mathrm{ab}}$ & $93.9 \pm 1.2^{\mathrm{a}}$ \\
Total fecundity & $29.0 \pm 0.5^{\mathrm{c}}$ & $48.1 \pm 1.1^{\mathrm{b}}$ & $58.9 \pm 1.3^{\mathrm{b}}$ & $54.2 \pm 8.0^{\mathrm{b}}$ & $84.9 \pm 2.6^{\mathrm{a}}$ \\
$\begin{array}{c}\text { Daily fecundity } \\
\text { Pre-oviposition } \\
\text { period (day) }\end{array}$ & $2.0 \pm 0.1^{\mathrm{d}}$ & $3.2 \pm 0.2^{\mathrm{c}}$ & $3.6 \pm 0.3^{\mathrm{bc}}$ & $4.5 \pm 0.2^{\mathrm{b}}$ & $5.6 \pm 0.3^{\mathrm{a}}$ \\
\hline
\end{tabular}

Data are expressed as mean reproduction parameters \pm SE. Per row, percentages followed by different letters are significantly different $(\mathrm{P}<0.05$, Tukey HSD test $)$.

${ }^{1}$ MFRC for spirotetramat $=50 \mathrm{mg} / \mathrm{ml}$

${ }^{2}$ MFRC for abamectin $=9 \mathrm{mg} / \mathrm{ml}$

toxic to T. pyri, while it is very detrimental to all growth stages of $G$. occidentalis and adversely affects its fecundity (LEFEBVRE et al., 2011). Topical application of spirotetramat did not result in Bombus impatiens (Hymenoptera: Apidae) mortality, and it was more effective against insect pests by ingestion than by contact (BRUCK et al., 2009). Although topical application had no effects on bees, high mortality was seen when worker bees chronically ingested field concentrations of spirotetramat (RAMANAIDU \& CUTLER, 2013).

Abamectin is an agonist of the GABA (gammaaminobutyric acid) neurotransmitter in nerve cells and is able to bind to glutamate-gated chloride channels in nerve and muscle cells of invertebrates. BESARD et al. (2010) reported that abamectin was highly toxic and killed $100 \%$ of the workers of the bumblebee Bombus terrestris (Hymenoptera: Apidae). Also, abamectin was harmful to workers of $B$. impatiens following direct contact, and worker bumblebees consumed less pollen that was supplemented with abamectin (GRADISH et al., 2009). However, KRÄMER \& SCHIRMER (2007) considered that abamectin is safe to use with beneficial arthropods under field conditions due to its short environmental persistence, rapid uptake into treated plants and fast degradation of surface residues. Also, HAN et al. (2010) reported that, while beneficials may be killed when treated directly with spray oils or exposed to the vapor phase of essential oils, due to the short term of residual activity, they found no severe effects on the population of phytoseiid mites and other predations. In our laboratory studies, abamectin at $1 / 1,1 / 2,1 / 4$ and $1 / 8$ of its MFRC was very harmful based on high acute toxicity, so could not be recommended for use in an IPM program. In agreement with our results, other recent studies also categorized abamectin as harmful to predators, such as Tamarixia triozae (Hymenoptera: Eulophidae) (LIU et al., 2012), Ganaspidium nigrimanus (Kieffer) and Neochrysocharis formosa (Westwood) (Hernandez et al., 2011), Cryptolaemus sp., $C$. sanguinea and $H$. axyridis (SEAL et al., 2006), Phytoseiulus persimilis (Acari: Phytoseiidae) and Amblyseius fallacis (Acari: Phytoseiidae) (BOSTANIAN \& AKALACH, 2006). We also tested abamectin at lower (sublethal) dosages of 1/16 of its MFRC, and observed severe decreases in total and daily fecundity of $M$. sexmaculatus. KIM et al. (2006) found abamectin caused high adult mortality in Deraeocoris brevis (Uhler) (Hemiptera: Miridae) at the full rate, but no mortality at the $10 \%$ rate although fecundity was decreased. Similarly, Bostanian \& 
AKALACH (2006) found that abamectin at the rate recommended on the product label reduced the number of eggs laid by individual females of $P$. persimilis and A. fallacis. Although in our study, pre-oviposition period was not increased by abamectin exposure, BIN IBRAHIM \& SEK YEE (2000) reported that abamectin did increase the pre-oviposition period of Neoseiulus longispinosus (Acari: Phytoseiidae). Our results suggest that abamectin is not compatible with M. sexmaculatus and could not be used in IPM programs based on its strong lethal and sublethal effects. Higher TIER testing under field-related conditions that take account of environmental persistence may be informative.

In conclusion, this study is of importance to the field as our data on acute toxicity effects demonstrated that spirotetramat was harmless and can be compatible with augmentative releases of the coccinellid $M$. sexmaculatus. This confirms the benign profile of spirotetramat when used with predatory coccinellids, but those applying the insecticide need to respect safety periods. Accumulated dosages may reduce the effectiveness of these biological control agents by causing sublethal effects on prey consumption and through reduced fecundity (oviposition). However, we believe that spirotetramat is safe when used at its MFRC, considering that is also metabolized and diluted before reaching the natural enemies; the coccinellids are only maximally exposed to the MFRC at the moment of spraying. In marked contrast, abamectin was harmful and seems not to be compatible with $M$. sexmaculatus due to strong lethal and sublethal effects. However, further testing under more field-realistic conditions may be useful as these would also take environmental persistence into account.

\section{ACKNOWLEDGMENTS}

We gratefully acknowledge financial support from Research Council of Vali-e-Asr University of Rafsanjan. All authors disclose any conflict of interest involvement, financial or otherwise, that might potentially bias our work. In addition, we thank the two anonymous referees and the associate editor (dr. Nikki Watson) for their corrections and improvements of the manuscript.

\section{REFERENCES}

Аввотт WS (1925). A method of computing the effectiveness of an insecticide. Journal of Economic Entomology, 18: 265-267.

BAYER CROP SCIENCE. 2012. Spirotetramat(Movento, Ultor, Tihan). (Internet address: http://www. bayercropscience.com/bcsweb/cropprotection. nsf/id/spirotetramat.htm.).

BEERS EH \& SCHMIDT RA (2014). Impacts of orchard pesticides on Galendromus occidentalis: Lethal and sublethal effects. Crop Protection, 56: 16-24.

Besard L, Mommaerts V, VANDEVen J, Cuvelier X, Sterk G \& SMAGghe G (2010). Compatibility of traditional and novel acaricides with bumblebees (Bombus terrestris): a first laboratory assessment of toxicity and sublethal effects. Pest Management Science, 66: 786-793.

Bin IBRAHIM Y \& SEK YeE T (2000). Influence of sublethal exposure to abamectin on the biological performance of Neoseiulus longispinosus (Acari: Phytoseiidae). Journal of Economic Entomology, 93: 1085-1089.

Biondi A, Mommaerts V, Smagghe G, Viñuela E, ZAPPALÀ L \& DESNEUX N (2012). The non-target impact of spinosyns on beneficial arthropods. Pest Management Science, 68: 1523-1536.

Bostanian NJ \& AKalach M (2006). The effect of indoxacarb and five other insecticides on Phytoseiulus persimilis (Acari: Phytoseiidae), Amblyseius fallacis (Acari: Phytoseiidae) and nymphs of Orius insidiosus (Hemiptera: Anthocoridae). Pest Management Science, 62: 334-339.

BrÜCK E, Elbert A, Fischer R, KRUEger S, KÜHNhold J, KLUEKen AM, NAUEN R, NiebeS JF, RECKMANN U, SCHNORBACH HJ ,STEFFENS R \& VAN WAETERMEULEN X (2009). Movento an innovative ambimobile insecticide for sucking insect pest control in agriculture: biological profile and field performance. Crop Protection, 28: 838-844. 
CANDOlFi MP, Barrett KL, CAMPBell P, Forster R, Grandy N, Huet MC, Lewis G, OOMEN PA, SchMUCK R \& Vogt H (2001). Guidance document on regulatory testing and risk assessment procedures for plant protection products with non-target arthropods. In: CANDOLFI MP (eds), SETAC/ESCORT2 Workshop report, Wageningen.

CROFT BA (1990). Arthropod biological control agents and pesticides. John Wiley, New York.

Delpuech JM, Dupont $\mathrm{C} \&$ Allemand $\mathrm{R}$ (2012). Effects of deltamethrin on the specific discrimination of sex pheromones in two sympatric Trichogramma species. Ecotoxicology and Environmental Safety, 84: 32-38.

FARHADI R, AllahyaRi H \& CHI H (2011). Life table and predation capacity of Hippodamia variegata (Coleoptera: Coccinellidae) feeding on Aphis fabae (Hemiptera: Aphididae). Biological Control, 59: 83-89.

Gradish AE, SCOTT-DuPREE CD, SHIPP L, HARRIS CR \& FERGUSON G. (2009). Effect of reduced risk pesticides for use in greenhouse vegetable production on Bombus impatiens (Hymenoptera: Apidae). Pest Management Science, 66: 142-146.

HaN J, ChOi BR, LeE SG, Kim SI \& AhN YJ (2010). Toxicity of plant essential oils to acaricide-susceptible and -resistant Tetranychus urticae (Acari: Tetranychidae) and Neoseiulus californicus (Acari: Phytoseiidae). Journal of Economic Entomology, 103: 1293-1298.

HERNANDEZ R, GUO K, HARRIS MA \& LIU TX (2011). Effects of selected insecticides on adults of two parasitoid species of Liriomyza trifolii: Ganaspidium nigrimanus (Figitidae) and Neochrysocharis formosa (Eulophidae). Insect Science, 18: 512-520.

JACAS JA \& URBANEJA A (2010). Biological control in citrus in Spain: from classical to conservation biological control. In: CIANCIO A \& MUKERJI KG (eds), Integrated management of arthropod pests and insect borne diseases, Springer, Dordrecht: 61-72.

JOHNSON MW \& TABASHNIK BE (1999). Enhanced biological control through pesticide selectivity. In: Fisher T, Bellows TS, Caltagirone LE, DAHLSTEN DL, HufFAKER C \& GORDH G (eds), Handbook of Biological Control, Academic Press, San Diego: 297-317.

KIM DS, BROOKS DJ \& RIEDL H )2006(. Lethal and sublethal effects of abamectin, spinosad, methoxyfenozide and acetamiprid on the predaceous plant bug Deraeocoris brevis in the laboratory. Biocontrol, 51: 465-484.

KRÄMER W, SCHIRMER U, JESCHKE P \& WitsCHEL $M$ (eds) (2007). Modern Crop Protection Compounds, Volume 3. Wiley, Weinheim.

Lefebvre M, Bostanian N, ThistlewoOd HAM, MAUFFETTE Y \& RACETTE G (2011). A laboratory assessment of the toxic attributes of six 'reduced risk insecticides' on Galendromus occidentalis (Acari: Phytoseiidae). Chemosphere, 84: 25-30.

LiU TX, Zhang YM, Peng LN, RoJAs P \& TRUMBle JT (2012). Risk assessment of selected insecticides on Tamarixia triozae (Hymenoptera: Eulophidae), a parasitoid of Bactericera cockerelli (Hemiptera: Trizoidae). Journal of Economic Entomology, 105: 490-496.

MAUS C (2008). Ecotoxicological profile of the insecticide spirotetramat. Bayer Crop Science, 61: 159-180.

MEHRNEJAD MR (2001). The current status of pistachio pests in Iran. Options Méditerranéenes, 56: 315-322.

MEHRNEJAD MR (2003). Pistachio psylla and other major psyllids of Iran. Publication of the Agricultural Research and Education Organization, Tehran.

MichAUD JP (2002). Relative toxicity of six insecticides to Cycloneda sanguinea and Harmonia axyridis (Coleoptera: Coccinellidae). Journal of Entomological Science, 37: 82-93.

Moens J, De ClercQ P \& Tirry L (2011). Side effects of pesticides on the larvae of the hoverfly Episyrphus balteatus in the laboratory. Phytoparasitica, 39: 1-9.

Moens J, Tirry L \& De ClercQ P (2012). Susceptibility of cocooned pupae and adults of the parasitoid Microplitis mediator to selected insecticides. Phytoparasitica, 40: 5-9.

Planes L, Catalan J, Tena A, Porcuna JL, JACAS JA, IZQUIERDO J \& URBANEJA A (2013). Lethal and sublethal effects of spirotetramat on the mealybug destroyer, Cryptolaemus montrouzieri. Journal of Pest Science, 86: 321-327.

PRATT PD \& CROFT BA (2000). Overwintering and comparative sampling of Neoseiulus fallacis (Acari: Phytoseiidae) on ornamental nursery plants. Environmental Entomology, 29: 10341040. 
RAMANAIDU K \& CUTLER GC (2013). Different toxic and hormetic responses of Bombus impatiens to Beauveria bassiana, Bacillus subtilis and spirotetramat. Pest Management Science, 69: 949-954.

SCHNORBACH J, ELBERT A, LABORIE B, NAVACERRADA J, BANGELS E \& GOBIN B (2008). Movento, an ideal tool for integrated pest management in pomefruit, citrus and vegetables. Bayer Crop Science, 61: 377-402.

SEAL DR, CIOMPERLIK M, RichaRdS ML \& KLASSEN W (2006). Comparative effectiveness of chemical insecticides against the chilli thrips, Scirtothrips dorsalis Hood (Thysanoptera: Thripidae), on pepper and their compatibility with natural enemies. Crop Protection, 25: 949-955.

SCHNeIder M, SMagghe G, Pineda S \& Viñuela E (2008). Studies on ecological impact of four IGR insecticides in adults of Hyposoter didymator (Hym., Ichneumonidae): Pharmacokinetics approach. Ecotoxicology, 17: 181-188.

U.S. ENVIRONMENTAL PROTECTION AgENCY (2008). Pesticide fact sheet: Mandipropamid. Office of Prevention, Pesticides and Toxic Substances. United States Environmental Protection Agency, Washington D.C.
WRINN KM, EVANS SC \& RYPSTRAA (2012). Predator cues and herbicide affect activity and emigration in agrobiont wolf spider. Chemosphere, 87: 390396.

YouAn YN, SeO MJ, ShIN JG, JANG C \& YU YM (2003). Toxicity of greenhouse pesticides to multicolored Asian lady beetle, Harmonia axyridis (Coleoptera: Coccinellidae). Biological Control, 28: 164-170.

ZOtTI MJ, GrutzMACHer AD, LOPES IH \& SMAGGHE G (2013). Comparative effects of insecticides with different mechanisms of action on Chrysoperla externa (Neuroptera: Chrysopidae): Lethal, sublethal and dose-response effects. Insect Science, 20: 743-752.

Received: 5 January 2016

Accepted: 8 August 2016

Branch editor: Karen Smeets 